\title{
Lateral
}

Journal of the Cultural Studies Association

\section{Review of Insurgent Aesthetics: Security and the Queer Life of the Forever War by Ronak K. Kapadia (Duke University Press)}

\author{
by Eric Vazquez | Book Reviews, Issue 9.2 (Fall 2020)
}

\begin{abstract}
Ronak K. Kapadia's deeply conversant and well researched Insurgent Aesthetics: Security and the Queer Life of the Forever War brings queer, affectoriented methodologies to bear on an analysis of Arab, Muslim, and South Asian diasporic art. It is these communities after all, Kapadia points out, who undergo increased scrutiny in the United States and Europe after September 11, 2001. According to the author, these diasporic artists engage in an insurgent aesthetic "against empire's built sensorium," which is a visual cultural practice that offers an alternative embodied critique of "US empire's perverse logics of carcerality, security, and war" (10).
\end{abstract}

KEYWORDS $\underline{9 / 11}, \underline{\text { aesthetics, }}, \underline{\text { art }}, \underline{\text { drone, insurgent, terrorism, war }}$

Insurgent Aesthetics: Security and the Queer Life of the Forever War. By Ronak K. Kapadia. Durham; Duke University Press, 2019, 334 pp. (Hardcover) ISBN:

9781478003717. US List: \$104.95 (Paperback) Paper ISBN: 9781478004011 US List: $\$ 28.95$.

In 2007, Iraqi exile artist Wafaa Bilal occupied a Chicago gallery in which he invited online participants "shoot" him remotely via a robotic paintball gun. The paintballs launched at close range produced "excruciating" pain and the shots fired at all hours. The artist hoped that abjection before his virtual audience/aggressors might spark consciousness about the embodied ramifications of the ongoing Global War on Terror (GWoT). Entitled Domestic Tension, this work reaches into what Ronak K Kapadia describes as "'the comfort zone,' those more mundane settings, far from the killing fields, in which war enlists and acts upon our senses" (90). Kapadia's richly referenced and well researched Insurgent Aesthetics:

Security and the Queer Life of the Forever War brings queer, affect-oriented methodologies to bear on an analysis of Arab, Muslim, and South Asian diasporic art like Bilal's piece above. It is these communities after all, Kapadia points out, who undergo increased scrutiny in the United States and Europe after September 11, 2001. According to the author, these diasporic artists engage in an insurgent aesthetic "against empire's built sensorium," which is a visual cultural practice that offers an alternative embodied critique of "US empire's perverse logics of carcerality, security, and war" (10). In spite of the transnational machinations of the GWoT, both the artists under analysis and Kapadia himself emphasize the limitations and failures of these conflicts-a refreshing insight that flies in the face of what Mark Neocleous describes as the "fetish of 9/11" which scholars seem to agree is the "the political event of our time."-1 Insurgent aesthetics activate "more sensuous ways of knowing and feeling" that both challenge the omniscience of US 
security powers and build affinities between war's victims in the Greater Middle East and racialized subjects within the United States (9).

As Kapadia is quick to acknowledge, Insurgent Aesthetics is profoundly indebted to other US "minoritarian" fields: namely queer theory, postcolonialism, Native American studies, African-American studies, and feminist traditions of critique. By drawing on this diverse range of scholarship, Kapadia hopes that these frameworks will resound through the diasporic art he examines, exposing the ways in which security discourse, racism, and capitalism are co-constitutive processes. With this dense assemblage of theoretical perspectives in tow, Kapadia theorizes the cultural work of insurgent aesthetics as a queer calculus, a "slantwise" perspective of the abstract numbering of casualties, injuries, and financial costs through which US imperial discourse evaluates war (22).

In the book's first chapter, Kapadia synthesizes the means by which security states aggregate and diagram the socio-cultural sphere of the GWoT. In doing so, he establishes the exigence for queering imperial calculations. Like other scholars of war before him, he examines the coincidence of remote sight—manifest through predator drones-and killing. To the drone's visualization of battlespace he adds the US military's endeavor to instrumentalize anthropological knowledge of culture for the conduct of war, a Human Terrain System (HTS). HTS and drone attacks define, Kapadia holds, contemporary counterinsurgency strategy with its unique penchant for ocular domination of a colonized subjects. As with other colonial structures of power, the "forever war" produces new modes of racialization. He cites the "double-tap phenomenon," where drone pilots frequently discharge multiple missiles in rapid succession that may kill specific targets but also the rescuers of other injured bodies caught up in the same terrain. This particular phenomenon results in the disarticulation of community bonds, "disaggregating embattled Muslim populations beset by bombs. I see this practice," he argues, "as a different mode of racialization" (69). Doubtless, counterinsurgency tactics socialize traumas, but they also facilitate fugitive conditions in which new modes of solidarity might emerge, as later chapters reveal.

Visual and performance artists, with heritage ties to the GWoT spaces, envision the ramifications of these seemingly boundless conflicts by recasting them through corporeality, disrupting what Kapadia takes to be the removed ocular bias of contemporary military strategy. Pieces like Wafaa Bilal's Domestic Tension alongside his ...And Counting (2010) translate counterinsurgency's accumulative and cartographic logics onto the surface of his body. In the latter, Bilal undergoes a 24-hour performance, in which he tattoos both the names of Iraqi cities and 105,000 dots, representing those that died as a result of the invasion and occupation of Iraq. Kapadia threads together Bilal's compelling works by considering the social power of public abjection. Drawing on Jack Halberstam's previous analysis of Yoko Ono's Cut Piece (1964), Kapadia suggests Bilal's work too transmits a "radical passivity," one in which self-punishment and discipline transmit the "shadow archive of resistance" (88).

If Bilal's art reconstructs empire as skin work, the diasporic artists examined in chapter three breach the surface into "empire's innards," to use Kapadia's language. Works produced by The Visible Collective, for example, highlight the GWoT's effects on the domestic sphere, namely the modes of racialization at home that recast Arab, Muslim, and South Asian populations in the US as a newly emergent threat. The collective's Driving While Black Becomes Flying While Brown features repeated columns of mugshots, processed through rounds of photocopying, in effect blurring together faces from Black to 
brown to white. Rather than default to the title's suggested reading that Arabs, Muslims, and South Asian have somehow supplanted African-Americans as the target of racialized statecraft, Kapadia argues that the piece scrambles "older racial identifications and inherited antagonisms" such that precarious cross-ethnic coalitions become imaginable (119). There's an affective dimension to this work as well, conjuring what Kapadia describes as "warm data," following the art collective The Index of the Disappeared (105). The "warm data" in Rajkamal Kahlon's series Did You Kiss the Dead Body (2009-12) emerges through visual juxtaposition: layering Renaissance anatomical drawings, Medieval torture diagrams, and the imagery of nineteenth-century physiognomy atop declassified CIA "enhanced interrogation" documents. Seeming to make visually evident what the documents merely report, Kapdia asserts that these juxtapositions produce a "seething presence" of the bodies mutilated and disappeared in the prosecution of the GWoT (144).

Insurgent Aesthetics' final chapter and epilogue offer the flipside of embodied critique, by investigating aerial, even galactic, perspectives in art and politics. As if to complicate the allegory of "rising from submission" implicit in the process of uplift, Kapadia threads together the speculative-fiction inflections of Palestinian artist Larissa Sansour's video work, the postnationalist politics of the Boycott Divestment Sanctions movement, and Patricia Okoumou's 2018 scaling of the Statue of Liberty. While these chapters provoke fascinating insights, such as the observation that representations of Palestinian astronauts in Sansour's videos evoke "To be without gravity untethered by the weight of the body and its inscriptions, is a queer feminist decolonial sensation" (185), they also seem to strain against one Kapadia's core assertions: that there is a queer aesthetic at work in each of the manifestations he examines. That is, for some of us, bodily heft may be intrinsic to queernesss, and paradoxically, the experience described as queer above bears a strong resemblance to the phenomenology of the drone pilot who is both disembodied and yet capacitated with corporeal faculties. Just as crucial, what theory of aesthetics (or the aesthetic) could hold together works operating in such different registers of visual and performative practice? Of course, such paradoxes may be the inevitable result of mapping a transnational artistic/political formation that addresses conflicts fought on numerous fronts and using multifarious means. Nevertheless, there is much to be learned from Kapadia, whose ambitious monograph traffics between a profound appreciation for the ramifications of US imperialism, an eye for congruencies between divergent strains of comparative ethnic studies, and an enthusiasm for the critical talents of minoritarian cultural production.

\title{
Notes
}

1. Neocleous, Mark, "War is Peace, Peace is Pacification," Radical Philosophy, no. 159 (January/ February 2010): 9.

\section{Author Information}

\author{
Eric Vazquez
}


Eric Vázquez is assistant professor in American studies and Latino studies at University of lowa. His scholarship emphasizes the cultural, political, military, and economic bonds that link populations and institutions in the United States to Central America. In his current book project, States of Defeat: US Imaginaries of Central American Revolution, explores how thwarted ambitions for revolution in Nicaragua, El Salvador, and Guatemala give rise to ambivalent, outraged, cynical, and mournful affects for novelists, intellectuals, immigrants, and military technocrats living in the US. His work has been published in Modern Fiction Studies, Theory and Event, and Latino Studies.

View all of Eric Vazquez's articles.

\section{Article details}

Eric Vazquez, "Review of 'Insurgent Aesthetics: Security and the Queer Life of the Forever War' by Ronak K. Kapadia (Duke University Press)," Lateral 9.2 (2020).

https://doi.org/10.25158/L9.2.14

This content is licensed under a Creative Commons Attribution-NonCommercial 4.0 International License. Copyright is retained by authors.

Lateral is the peer-reviewed, open access journal of the Cultural Studies Association.

ISSN 2469-4053 